\title{
Isolated Meningitis and Lacrimal Gland Abscess due to Odontogenic Sinusitis: Case Report
}

\author{
Meningitis Aislada y Absceso de la Glándula Lagrimal \\ debido a Sinusitis Odontogénica: Reporte de un Caso
}

\author{
P. Gradoni'; G. Latini'; M. Battistoni² \& L. D’Ascanio'
}

GRADONI, P.; LATINI, G.; BATTISTONI, M. \& D'ASCANIO, L. Isolated meningitis and lacrimal gland abscess due to odontogenic sinusitis: Case report. Int. J. Odontostomat., 14(4):586-589, 2020.

\begin{abstract}
Our objective was report an extremely rare case of isolated meningitis and suppurative dacrioadenitis as consequences of odontogenic sinusitis. We describe the diagnostic tools including imaging and culture, as well as surgical treatment and follow-up. Our final diagnosis was odontogenic sinusitis caused by Streptococcus Anginosus complicated by isolated meningitis and lacrimal gland abscess. Urgent surgical treatment to restore the paranasal sinuses and drainage of the lacrimal gland was performed. Culture from purulent material collected from maxillary sinus indicated the targeted therapy. Clinical assessment and imaging obtained 20 days after surgery demonstrated successful results. This case emphasizes the importance of evaluating intracranial complications of rinosinusitis, the need to search for a dental infection when a maxillary sinusitis is encountered, the key role of a thorough diagnostic workup in order to plan a comprehensive and effective surgical treatment, as well as targeted medical therapy.
\end{abstract}

KEY WORDS: meninigitis, lacrimal gland abscess, sinusitis, dental infection.

\section{INTRODUCTION}

Periorbital and facial swelling secondary to rhinosinusitis is a common condition, particularly in children (Parvizi et al., 2012). Acute bacterial sinusitis complications, in fact, involve local tissue and the orbit, while intracranial involvement is the least affected (Benevides et al., 2015). Subdural empyema is the most common intracranial complication of acute bacterial sinusitis (Martines et al., 2014). Another route of spread of acute sinusitis is the lacrimal gland. Suppurative dacrioadenitis represents however an extremely rare complication (Patel et al., 2003). Also a dental infection may often be seen with facial and periorbital swelling and in rare cases has the capability to cause an intracranial infection. Brain abscess is the most common intracranial complication of dental infections (Fukushima et al., 2012). We describe a case in which oral infection, pan sinusitis, suppurative dacrioadenitis and intracranial involvement were simultaneously present. A Medline search has been performed regarding intracranial infection of sinuses and dental origin as well as suppurative dacrioadenitis.
Only articles in English were considered. To our knowledge an infective spread like this has never been described before. Diagnostic features and treatment strategy is discussed.

\section{CASE REPORT}

A 14 year-old boy presented to the Emergency Room with headache, vomit, left-sided nasal obstruction and left-sided periorbital swelling. He was admitted to Pediatric Unit with clinical diagnosis of ethmoiditis and orbital cellulitis. Body temperature was $38.5^{\circ} \mathrm{C}$, white cell blood count was $12,5 \times 103$ with $78.7 \%$ neutrophils and reactive C protein was $4 \mathrm{mg} /$ $\mathrm{dL}$. He had no comorbidities or significant medical history. Urgent computed tomography (CT) scan revealed periapical granulomas and a wide fistula between alveolar recess and maxillary antrum together with a complete obliteration of the left-sided paranasal

\footnotetext{
${ }^{1}$ Operative Unit of Otorhinolaryingology, Marche Nord Hospital, Pesaro - Fano, Italy.

${ }^{2}$ Operative Unit of Odontostomatology, Marche Nord Hospital, Pesaro - Fano, Italy.
} 
sinuses (Fig. 1). Due to the central symptoms, magnetic resonance (MR) was also obtained. The latter added two crucial information: contrast enhancement of the fronto-parietal meninx and fluid collection in the lacrimal gland (Fig. 2a,b). Thus a diagnosis of left-sided pan sinusitis complicated by isolated meningitis and suppurative dacryoadenitis was made. Blood culture was negative. Empirical treatment with ceftriaxone, metronidazole and linezolid was administered. Urgent

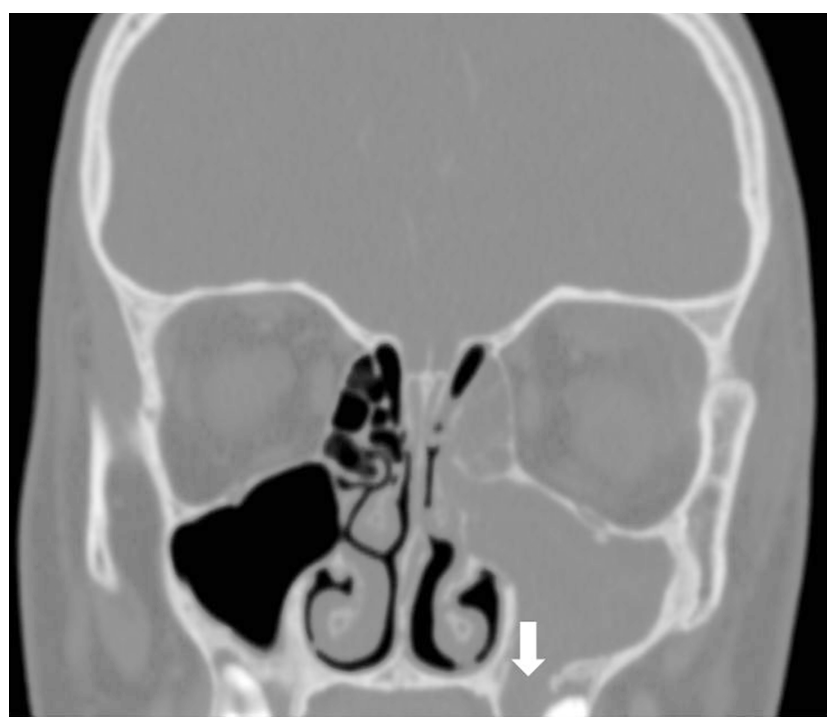

Fig. 1. White arrow shows a wide fistula between alveolar recess and maxillary antrum. surgical treatment under general anesthesia consisted of extraction of the left-sided upper first molar tooth and repair of the fistula with local flap; endoscopic sinus surgery with antrotomy, antero-posterior etmoidotomy and frontal sinusotomy (Draf1); finally an external drainage of the left-sided lacrimal gland was performed. Culture from purulent material collected from maxillary sinus revealed Streptococcus Anginosus.

Antibiotic treatment was modified in accordance with the antibiogram and linezolid was replaced by vancomycin. Postoperative course was characterized by gradual improvement of symptoms and clinical conditions. Inflammatory markers (erythrocyte sedimentation rate, $\mathrm{C}$ reactive protein and procalcitonin concentration) slowly decreased until normal range. Magnetic resonance obtained 20 days after surgery demonstrated patent paranasal sinuses, lacrimal abscess resolution and disappearing of the meningeal enhancement.

\section{DISCUSSION}

Intracranial bacterial infections such as meningitis, abscess and subdural empyema have a mortality rate that varies from $5 \%$ to $32 \%$ (Brook, 2006; Fukushima et al., 2012). A recent paper by Neidert et
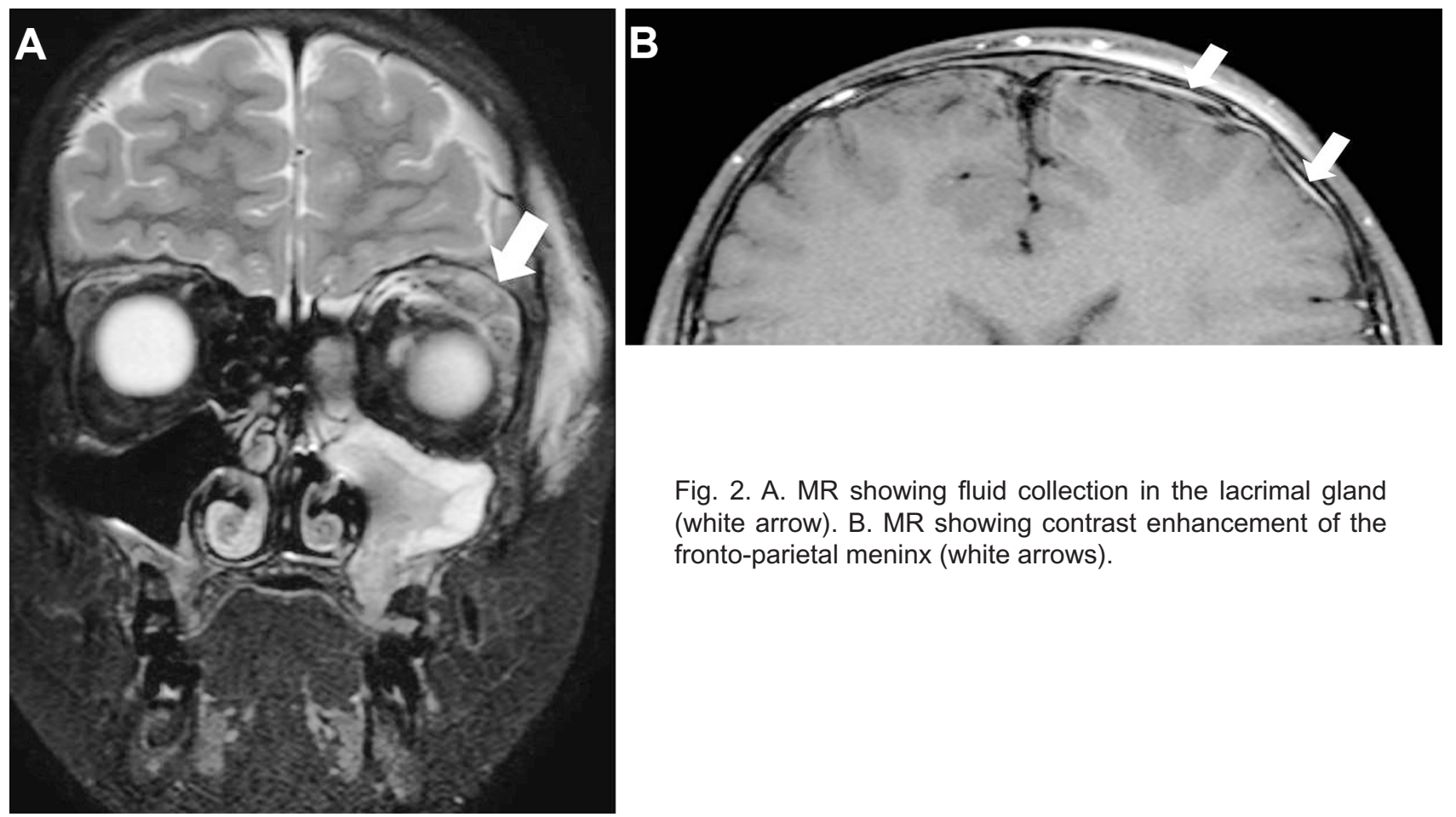

Fig. 2. A. MR showing fluid collection in the lacrimal gland (white arrow). B. MR showing contrast enhancement of the fronto-parietal meninx (white arrows). 
al. (2015) on brain abscesses stated that the infection is linked to an oral/dental source in $23 \%$ of cases and to a sinusitis in $14 \%$ of cases, followed by cardiac source $(14 \%)$, while no specific origin of infection can be determined in other cases (43\%). According to the review conducted by Moazzam et al. regarding intracranial bacterial infections of oral origin, the hematogenous spread appears to be the more important pathophysiological route of spread. Most frequently the central nervous system infection is represented by an abscess (frontal lobe in $31.7 \%$ of cases, parietal lobe in $21.7 \%$ and temporal lobe in $13.7 \%$ ) while isolated meningitis resulted to be unusual (5 \% of cases) (Moazzam et al., 2015; Lajolo et al., 2019). Moreover, they found that caries with periapical involvement and periodontitis are the oral pathologies most frequently responsible of an intracranial bacterial infection (Ewald et al., 2006; Moazzam et al.). On the other hand, acute bacterial sinusitis (ABS) may also be complicated with intracranial involvement. Subdural empyema is the most common complication of ABS, and the usual route of dissemination to central nervous system (CNS) is considered to be the contiguity with paranasal sinuses, mostly the frontal sinus (Benevides et al.). Among these two sources of CNS infections (oral and sinusal) there is an important difference regarding microbiology. Streptococcus pneumoniae, Haemophilus influenzae and Moraxella catarrhalis are commonly associated with sinusitis while odontogenic infection is a mixed aerobic/anareobic infection (Eufinger \& Machtens, 2001; Akashi et al., 2017). Common bacteria reported in oral infections, include gram positive organisms such as Streptococcus viridans, particularly the anginosus subgroup, and anaerobes such as Peptostreptococcus, Prevotella and Fusobacterium (Moazzam et al.). Finally, the association between acute sinusitis and lacrimal gland abscess represents an extremely rare condition (Lai et al., 2017; Savoie et al., 2017). In a recent literature review, Parvizi et al. found only six cases of periorbital cellulitis, in the context of sinusitis, complicated by lacrimal gland abscess. The case we describe represents an exceptional conjunction between odontogenic infection and sinusitis spread. The odontogenic origin of infection has been demonstrated by the isolation of Streptococcus Anginosus in the maxilary sinus while the intracranial involvement resulted from contiguity with frontal sinus. Moreover, with the same route of spread, i.e. contiguity, sinusitis caused the lacrimal abscess. Our case report gave rise to some important considerations about acute sinusitis and dental infections: a) severe headache and vomiting associated to a sinusitis must consider intracranial involvement, thus an MRI should promptly be obtained; b) when CT scan shows maxillary sinusitis, a dental infection should always be suspected and investigated; c) to understand the origin of infection is of paramount importance in order to plan a comprehensive and effective surgical treatment; d) culture from purulent material collected during surgery and antibiogram allow targeted medical therapy.

\section{CONCLUSIONS}

- headache not responding to conventional painkillers in association with acute sinusitis has to be investigated with magnetic resonance to rule out central complications.

- when maxillary sinus is involved a dental infection should always be suspected, investigated and treated.

- lateral orbital swelling may conceal a lacrimal gland abscess.

- to collect and culture purulent material during sinus surgery is of paramount importance especially when central involvement is present.

GRADONI, P.; LATINI, G.; BATTISTONI, M. \& D'ASCANIO, L. Meningitis aislada y absceso de la glándula lagrimal debido a sinusitis odontogénica: Reporte de un caso. Int. J. Odontostomat., 14 (4):586-589, 2020.

RESUMEN: En este estudio se informa un caso extremadamente raro de meningitis aislada y dacrioadenitis supurativa, como consecuencia de sinusitis odontogénica. Describimos las herramientas de diagnóstico que incluyen imágenes y cultivo, como también el tratamiento quirúrgico y el seguimiento. El diagnóstico final fue de sinusitis odontogénica causada por estreptococo anginoso complicado por una meningitis aislada y el absceso de la glándula lagrimal. Se realizó un tratamiento quirúrgico de urgencia para restaurar los senos paranasales y drenar la glándula lagrimal. Se determinó el tratamiento de acuerdo a los resultados de cultivo del seno maxilar. La evaluación clínica y las imágenes obtenidas 20 días después de la cirugía demostraron resultados exitosos. Es importante la evaluación de las complicaciones intracraneales de la rinosinusitis además de la necesidad de considerar una infección dental frente a una sinusitis maxilar. Por otra parte, es clave una evaluación exhaustiva de diagnóstico para planificar un tratamiento quirúrgico completo y efectivo, así como el tratamiento médico.

PALABRAS CLAVE: meninigitis, absceso de la glándula lagrimal, sinusitis, infección dental. 


\section{REFERENCES}

Akashi, M.; Tanaka, K.; Kusumoto, J.; Furudoi, S.; Hosoda, K. \& Komori, T. Brain abscess potentially resulting from odontogenic focus: report of three cases and a literature review. J. Maxillofac. Oral Surg., 16(1):58-64, 2017.

Benevides, G. N.; Salgado Jr., G. A.; Ferreira, C. R.; Felipe-Silva, A. \& Gilio, A. E. Bacterial sinusitis and its frightening complications: subdural empyema and Lemierre syndrome. Autops. Case Rep., 5(4):19-26, 2015.

Brook, I. Microbiology of intracranial abscesses associated with sinusitis of odontogenic origin. Ann. Otol. Rhinol. Laryngol., 115(12):917-20, 2006.

Eufinger, H. \& Machtens, E. Purulent pansinusitis, orbital cellulitis and rhinogenic intracranial complications. J. Craniomaxillofac. Surg., 29(2):111-7, 2001.

Ewald, C.; Kuhn, S. \& Kalff, R. Pyogenic infections of the central nervous system secondary to dental affections--a report of six cases. Neurosurg. Rev., 29(2):163-6, 2006.

Fukushima, K.; Noda, M.; Saito, Y. \& Ikeda, T. Streptococcus sanguis meningitis: report of a case and review of the literature. Intern. Med., 51(21):3073-6, 2012.

Lai, T. H. T.; Lai, F. H. P.; Chan, T. C. Y.; Young, A. L. \& Chong, K. K. L. Lacrimal gland abscess in children: Two case reports and literature review. Orbit, 36(6):468-72, 2017.

Lajolo, C.; Favia, G.; Limongelli, L.; Tempesta, A.; Zuppa, A.; Cordaro, M.; Vanella, I. \& Giuliani, M. Brain abscess of odontogenic origin in children: a systematic review of the literature with emphasis on therapeutic aspects and a new case presentation. Acta Otorhinolaryngol. Ital., 39(2):67-74, 2019.

Martines, F.; Salvago, P.; Ferrara, S.; Mucia, M.; Gambino, A. \& Sireci, F. Parietal subdural empyema as complication of acute odontogenic sinusitis: a case report. J. Med. Case Rep., 8:282, 2014.

Moazzam, A. A.; Rajagopal, S. M.; Sedghizadeh, P. P.; Zada, G. \& Habibian, M. Intracranial bacterial infections of oral origin. J. Clin. Neurosci., 22(5):800-6, 2015.

Neidert, M. C.; Karlin, K.; Actor, B.; Regli, L.; Bozinov, O. \& Burkhardt, J. K. Preoperative C-reactive protein predicts the need for repeated intracerebral brain abscess drainage. Clin. Neurol. Neurosurg., 131:26-30, 2015.

Parvizi, N.; Choudhury, N. \& Singh, A. Complicated periorbital cellulitis: case report and literature review. J. Laryngol. Otol., 126(1):94-6, 2012.

Patel, N.; Khalil, H. M. B.; Amirfeyz, R. \& Kaddour, H. S. Lacrimal gland abscess complicating acute sinusitis. Int. J. Pediatr. Otorhinolaryngol., 67(8):917-9, 2003.

Savoie, B.; Rodgers, R. \& Gorski, M. Lacrimal gland abscesses: Case series and literature review. Orbit, 36(6):428-32, 2017.

\author{
Corresponding author: \\ Paolo Gradoni MD \\ via Vittorio Veneto 2 \\ 61032 Fano (PU) \\ ITALY
}

Email: paologradoni@gmail.com

Received: 07-03-2020

Accepted: 08-05-2020 